\title{
Towards the Sustainable Development by 2020: aße Malaysia Perspective on Economic Growth and Research House Wellbeing
}

\section{Shadiya Mohamed Salleh Baqutayan*, Sharizal Abdul Shatar, Husni Alhan Md. Salimun, Norihan Abu Hassan}

Perdana School of Science, Technology and Innovation Policy, Universiti Teknologi Malaysia, Kuala Lumpur, MALAYSIA

*E-mail for correspondence: shadiya.kl@utm.my

Received: Nov 26, 2016;

Accepted: Jan 28, 2016;

Published: Mar 11, 2017

Source of Support: Nil

No Conflict of Interest: Declared

\begin{abstract}
This paper has prioritizes on the impact of national growth on wellbeing. This is a review paper that contributes to define the 14 components of Malaysia Wellbeing Index (MWI, 2012) and its relation to country's economic growth (the Gross Domestic Products (GSP)). The aim is to introduce and analyze the 10th Malaysia Plan (10MP), the 11th Malaysia plan Strategic Thrusts, achievement from macroeconomic indicators, average monthly incomes, Malaysia Wellbeing Index, and the sustainability by 2020 . The findings are of a great value to both theory and practice and have important implications for the country growth. Furthermore, the paper argues that although MWI projected to increase about $1.7 \%$ per year with estimated growth of 5-6\% every year from 2016-2020, some challenges are expected to undermine the target set by Economic Planning Unit (EPU) if not given a proper attention. Furthermore, the study shared few wellbeing indicators that used internationally, which only concerned about material aspects and outcomes without looking into the spiritual part of wellbeing. This paper concludes with possibilities for future study to consider the importance of spiritual aspect in the wellbeing index.
\end{abstract}

Keywords: Malaysia GDP, Wellbeing, Sustainability, MWI, MWR, 10MP, 11MP

\section{INTRODUCTION}

Malaysia economy has done tremendously well with Gross Domestic Product (GDP) growth of $6.2 \%$ per annum since 1970 despite encountered internal and external challenges. The growth was achieved through strategies that was outlined by the Government which are successful transform the economy from agriculture-based in 1970s, to manufacture-based in mid-1980s and to modern services in 1990s. The transforming was contributed by Science Technology and Innovation (STI) adaption which is play as catalyst in each era to spur the economic growth.

The quality of life of the people has also improved in line with the economy achievement. The improvement can be seen by the increase in both per capita income and the average household income. The per capita income has rose from the ranks of a low income economy in the 1970s to a high middle-income economy in 1992 and remains until today, while the average household income increase more than 20 time from 1970 to 2014. In addition, Malaysia also has made remarkable achievement from 1970 to 2014 in terms of reduce the poverty incidence and eradicate hard core poverty.
All the economic achievements have positively impacted the well-being of the people as reflected in Malaysian Well-being Report (MWR) 2013.The MWR is the first publication to assess the well-being of the people, encompassing with the following 14 components; communications, culture, education, environment, family, governance, health, housing, income and distribution, leisure, public safety, social participation, transport and working life. Figure 1 shows sub-composite of the components; which are divided into Economic and Social Wellbeing.

Nonetheless, the 21st century is expected to be very challenging for the Malaysian economy as reflected by the uncertainties global economic headwinds including the slowdown in China, Yuan devaluation and decline in prices of commodity as well as crude oil. At the same time, the domestic political turmoil affects consumer sentiment and investor confidence at home as well as abroad. The challenges are potentially having negative impact to the Malaysian economy growth and at the same time will affected the wellbeing of the people. Therefore, the Government should come out with strategies to overcome the challenges in order to ensure the wellbeing of the people will continue. 


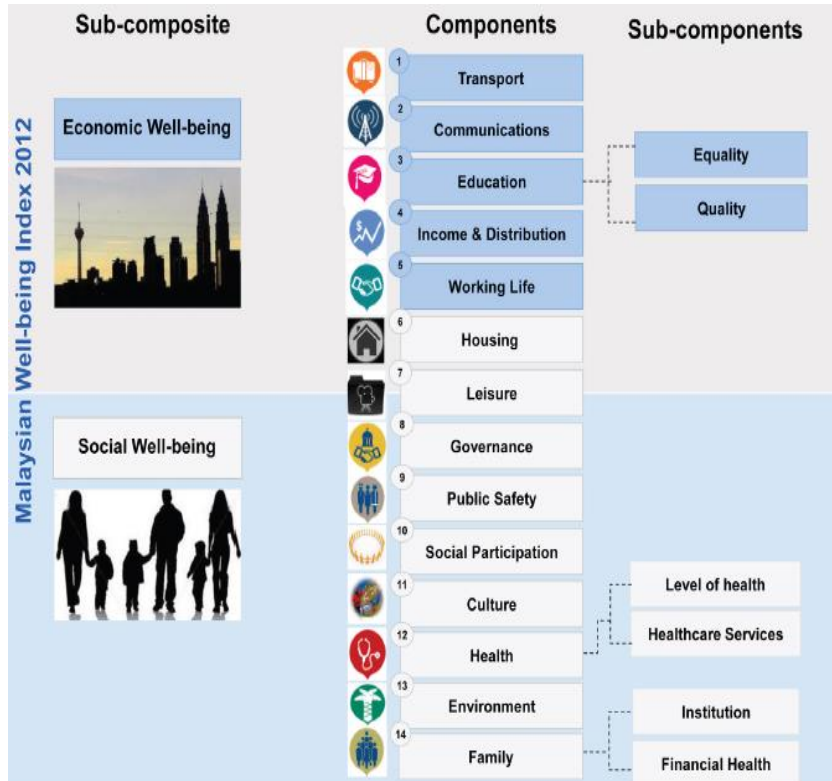

Figure 1: Components of Malaysian Well-being Index (MWI) 2012

Source: Malaysian Well-being Report 2013

The 11th Malaysia Plan (11MP) has outlined strategies to ensure the country achieve high-income country as stated in Vision 2020. The Plan has focused to unlock the productivity and transform innovation to wealth by using Science Technology and Innovation (STI) as a catalyst, which will create new economic opportunities. At the same time, efforts to elevate the wellbeing of people will be continued to ensure the people will be equipped with good ethical values, better quality of life, and higher living standards to provide foundation beyond year 2020 . This paper is divided into six sections. Section (1) will introduce the economic growth that measured by the GDP and that could contribute to the Malaysia Wellbeing Index (MWI). Then, the 11th Malaysia Plan Strategic Thrusts will be mapped with MWI components. Next, the Malaysia current achievement as stated in the 10th Malaysia Plan (10MP) will be introduced and how the government in the 11MP implemented it. Some challenges and gaps in the 11MP will also be discussed in this paper. Eventually, components of wellbeing index will be discussed for future improvement.

\section{Methodology}

This paper was prepared via document scanning and literature review from respective documents, which are Eleventh Malaysia Plan 2016-2020 and MWR 2013 produced by EPU. In addition to previous article on Malaysian Development Policies and benchmarking from other wellbeing indexes via International consultants.

\section{GDP vS WELLBEING}

Laily (1995) defined wellbeing is a human activities and it represents a state of life condition one has attained and experienced. Meanwhile, ESRC Research Group on
Wellbeing in Developing Countries (WeD, 2007) defined wellbeing as a state of being with others, where human needs are met, where one can act meaningfully to pursue one's goals, and where one enjoys a satisfactory quality of life. With an increase in income, a great number of needs are satisfied and a higher standard of wellbeing is achieved (Ahmad, N.F, et.al, 2012). Stiglitz (2012) mentioned that confirmed a reciprocal relationship between economic growth and wellbeing. MWR 2013 also established that economic growth would affect the wellbeing as Boston Consulting Group (BCG) (2012) also applied same approach in 2012 to measure other countries converting their wealth into wellbeing. India for example has experienced healthy growth in recent years and is making progress well in health; education and infrastructure as it also improve in income equality and poverty reduction.

For MWI, the relationship and elasticity between the indices and GDP were examined by testing the correlation coefficient and the coefficient of elasticity. The correlation test was applied to determine the magnitude of the relationship. Basically, correlation coefficient measures a linear association between two variables and the degree of linearity present as well as its direction, either positive or negative. In $10 \mathrm{MP}, \mathrm{MWI}$ increased $1.2 \%$ per year. Meanwhile in $11 \mathrm{MP}$, it projected to increase about $1.7 \%$ per year with estimated GDP growth of 5-6\% every year.

\section{$11^{\text {TH }}$ Malaysia Plan’s Strategic Thrusts Mapping}

Based on observation on the $11^{\text {th }} \mathrm{MP}$ document, proven that all six Strategic Thrusts measured in $11^{\text {th }} \mathrm{MP}$, emphasize on components in MWI 2012. To summarize the finding, we manage to map the relationship as follow:

\begin{tabular}{|l|l|c|}
\hline No & $\begin{array}{l}\text { 11 MP Strategic } \\
\text { Thrusts }\end{array}$ & MWI 2012 Components \\
\hline 1. & $\begin{array}{l}\text { Enhancing } \\
\text { inclusiveness towards } \\
\text { an equitable society }\end{array}$ & $\begin{array}{l}\text { i. Income and } \\
\text { distribution } \\
\text { ii. Family }\end{array}$ \\
\hline 2. & $\begin{array}{l}\text { Improving well-being } \\
\text { for all }\end{array}$ & $\begin{array}{l}\text { i. Health } \\
\text { ii. Housing } \\
\text { iii. Public safety } \\
\text { iv. Social participation }\end{array}$ \\
\hline 3. & $\begin{array}{l}\text { Accelerating human } \\
\text { capital development } \\
\text { for an advanced nation }\end{array}$ & $\begin{array}{l}\text { i. Education } \\
\text { ii. Working life } \\
\text { iii. Culture }\end{array}$ \\
\hline 4. & $\begin{array}{l}\text { Pursuing green growth } \\
\text { for sustainability and } \\
\text { resilience }\end{array}$ & i. Environment \\
\hline 5. & $\begin{array}{l}\text { Strengthening } \\
\text { infrastructure } \\
\text { support to } \\
\text { expansion }\end{array}$ & $\begin{array}{l}\text { i. Transport } \\
\text { ii. Communication } \\
\text { iii. Leisure }\end{array}$ \\
\hline 6. & $\begin{array}{l}\text { Re-engineering } \\
\text { economic growth for } \\
\text { faster prosperity }\end{array}$ & i. Governance \\
\hline
\end{tabular}

Table 1: Relationship between MWI 2012 Components 


\section{Where Are We Now?}

In 10MP, Malaysia enjoyed average 5.3\% real GDP growth with world GDP growth at 3.6\%. National per capita income (GNI) in 2015 is at RM36, 937 while average monthly household income in 2014 was at RM6, 141, increased 52.6\% from RM4, 025 in 2009. Unemployment rate in 2015 is at $2.9 \%$. In well-being point of view, MWI was increased at $1.2 \%$ per annum.

\section{Where ARE We HEAdING To?}

From macroeconomic prospects, target was set for year 2016 to 2020. GDP growth expected to be at 5-6\% per annum. GNI per capita is projected to increase at RM54, 100 in year 2020, and average monthly household income is at RM10, 540. As job creation increased, unemployment rate is expected to decreased $0.1 \%$ to $2.8 \%$ by 2020 . As mention earlier, 11MP was set to increase MWI to $1.7 \%$ per annum, we will discuss some strategies to uplift the MWI from both economic and social components.

\section{Economic wellbeing}

In transportation, one of the strategies is to focus on developing highways for rural and rural-urban connectivity to achieve a balanced economic development. The highways will promote better connectivity and catalyze growth especially in the rural area. At the same time, rural roads, which are linked to the main roads, also will be given focus in the 11MP. Rural roads play vital role for rural area in order to provide access to basic public facilities like hospital and school. In addition, the rural roads also help to elevate poverty in the rural households by creating economic opportunities. Thus, the Government has target to construct 3,000 kilometers of paved rural roads during the 11MP period.

In 2020, $75 \%$ of Malaysia population will be living in cities; therefore it is essential for the Government to provide efficient urban public transport. Align with the increment of cities population by 2020; the Klang Valley Mass Rapid Transit (KVMRT) line 1 system will become operational during the Eleventh Plan. The KVMRT line 2 as and Light Rail Transit line 3 are in pipeline and expect to be completed by 2022 and 2020 to serve the urban residents as a reliable public transport to commute.

In communication, nowadays, digital infrastructure will not only be vital in bringing people together through communication channels, but it is a foundation of economic development, particularly in supporting the needs of business operation. In attending the needs, the 11MP has set target to cover $95 \%$ of populated area by broadband infrastructure by 2020 . Key infrastructure initiatives such as High-Speed Broadband 2 (HSBB 2), Sub-Urban Broadband (SUBB), and Digital Terrestrial Television (DTT) to be undertaken during the 11MP period. It is anticipated that the people and the business entity will benefit in terms of high quality of connectivity and digital infrastructure to enable them to communicate and connect to the global marketplace.

In education, education system plays crucial role to produce human capital with the knowledge and skills, as well as ethics and morality for Malaysia to become an advanced and inclusive nation by 2020. In the Eleventh Plan, the Government has set up three target in order to ensure the education system will be improved for better student outcomes. First target is to be at least on par with the international average in Programme for International Student Assessment (PISA) and Mathematics and Science Study (TIMSS) by emphasizing on Higher Order Thinking Skills (HOTS) in school curriculum to encourage students to be more creative and critical thinking. Second target is to achieve $100 \%$ enrolment from preschool to upper secondary by widen the access to all citizens in obtaining formal education and third target is to have at least two universities in Top 100 of the QS World University Rankings by 2020 by raising the quality of graduates and programmes as well as strengthening research for innovation in institutions of higher educations.

As projected in the $11 \mathrm{MP}$, there will be 1.5 million jobs created by 2020 that will be based on knowledge and innovation economic activities. $60 \%$ of the jobs are expected to require Technical and Vocational Education and Training (TVET) related skills. Therefore, the Government has targeted to increase intake of Sijil Pelajaran Malaysia leavers to TVET programmes from 164,000 persons in 2013 to 225,000 person in 2020. At the same time, the quality and delivery of TVET programmes will be enhanced to improve graduate employability and is expected to meet industry demand.

For income and distribution, efforts to will be emphasized by providing equitable opportunities for all Malaysian to participate in economic growth to improve their quality of life. In this respect, the Government has set targets to improve income inequality by reducing the Gini coefficient from 0.4014 in 2014 to 0.385 in 2020 . At the same time, the average household income is expected to increase at RM10, 540 in 2020 from RM 6,141 in 2014. These targets are aligned with Malaysia aspiration to growth with equity in achieving an advanced economy status with by 2020. The growing of the middle-class society will help Malaysia towards advance and more inclusive nation by 2020 .

In working life, the government realizes the importance of maximizing public servant's productivity for greater service delivery. In Eleventh Plan, the Government will provide greater flexibility in the public service by improving existing work 
arrangements for better work-life balance. This effort will allow public servants to still perform and raise productivity by balancing between their work and personal or family responsibilities.

\section{Social wellbeing}

For housing, government will continue to build affordable houses for poor, low and middle income households. After completion of 102, 200 in 10MP, six ministries were accountable to develop 606,000 more houses till 2020 together with 47,000 houses to be repaired for the poor. Some of the programs in rural and urban area are Program Bantuan Rumah (PBR), Program Perumahan Rakyat (PPR), Perumahan Rakyat 1Malaysia (PR1MA) and 1Malaysia Civil Servants Housing (PPA1M). Furthermore, financing schemes also provided to assist buyer like My First Home Scheme (MyHome) on funding their first house.

For leisure, MWI measures on paid TV subscription, cinema, recreational park and domestic hotels goers. However, in $11 \mathrm{MP}$, digital infrastructure was set up such as connected services from high speed broadband and digital terrestrial TV. The leisure component has become wider with rapid technology enhancement.

In governance aspect, fighting corruption, e-payment transaction and percentage of e-filing users are among the determinant sub-component in the MWI. In $11 \mathrm{MP}$, Malaysia is targeting to be at Top 30 in the corruption Perception Index by Transparency International. Transformation agenda in Public service also will be tailored for productivity through innovation in online services as we also aim to be Top 15 in UN e-Government Development Index. Services sector also will be strengthening to promote epayment or cashless transaction. The public government of the innovation system encompasses the organizational set-up that supports firms and other actors in their innovation activities, their nature and functions, and also the interactions among them (Cooke et al. 2000).

For public safety, crime index will be reducing up to $5 \%$ per annum and police and emergency response time will be at 8 minutes. Among the strategies is promoting awareness for effective prevention tightening regulations to stem crime. Collaboration among enforcement agencies to elevate perception of feeling safe. Meanwhile in road accidents, road fatalities index will be reduced from 2.9 to 2.0 per 10,000 registered vehicles in 2020. Heavier penalties will be imposing for errant drivers.

In social participation, public involvement in RELA, Rakan Cop and Voluntary Patrolling Scheme (SRS) will be. Non-Government Organization (NGO) also will encourage engaging in government project to build a shared sense of responsibility. NGO also will be encouraged to provide support services for rehabilitation and job placement programmes for former drug addicts.

For culture, development will be focus to promote a shared Malaysian culture and heritage. Support also will be given for talents to conserve cultural heritage like 'mak yong' and 'wayang kulit'. Artistic innovation and preservation also will be done to make it higher value and globally renowned. Among MWI indicators are membership in public libraries and museum visitors. We believe when Malaysian human capital development raise, the libraries membership also will be increased.

For health, universal access to quality healthcare will set to achieve 2.3 hospital beds per 1,000 populations as well as preparing 1:400 doctors to population ratio. Commitment will be given to expand the outreach programs like mobile doctors, flying doctor services, and village health promoters. Targets in 'infant mortality rate per 1,000 births' and 'estimated life expectancy' also will be improved accordingly from 10MP achievements, which are 6.5 death and 74.8 years.

For environment, green growth will be the key as $20 \%$ government procurement must be green and $22 \%$ recycling rate of household waste has set as a benchmark to achieve. Preservation of natural resources also crucial to secure water, air quality, and percentage of forested land. Among the plans are to gazette targeted $17 \%$ 'terrestrial and inland water areas' and $10 \%$ of 'coastal and marine areas' more as protected areas. As Sustainable Development Goals also set the Agenda 2030, combating climate change will be enhanced. Reduction up to $40 \%$ in Greenhouse Gasses (GHG) of GDP as compared to 2005 rate and generating 2,080 MW in renewable energy will be installed. Malaysia also joins 195 nations in a pledge in the $21^{\text {st }}$ Conference of the Parties (COP21) forum in Paris in December 2015.

Finally, for family component, family Well-being Index is targeted to increase from 7.5 in 2015 to 8.0 by 2020 with strengthening family institution's domains like relationship, economy, and religion/spiritual. Mean monthly household income also remains priority as many programmes to migrate the B40 towards a middle-class (M40) society.

\section{Challenges and Recommendation}

In this research, we analyzed four challenges that may affect the goals in 11MP towards achieving average GDP growth about $5-6 \%$ per annum in the next five years and 'Develop Nation' status by 2020. The challenges are as follow: 


\section{Human Capital Development}

Study in Cisco Connected World Technology Report 2015 suggested that companies that implement flexible work schedules have seen increases of up to $6 \%$ in productivity. As we want to secure talents, employers have to invest on preparing conducive working environment like home or opt to introduce work from home for some working disciplines like designers and architects. Meanwhile, as family institution getting strengthens, we might be facing situation of women quitting their job after became mother. To counter this issue, employers has to empower more women support facilities to entice women back to work as government targeting $59 \%$ women in the workplace.

\section{Citizen Acceptance and Paradigm Shift}

In $11 \mathrm{MP}$ energy chapter, nuclear power plant potential will be explored further. Unfortunately, public readiness still very minimal and negative perception on it rising like in the case of Lynas. In the other hand, confident in cashless transaction also still challenging to meet target 200 transaction per capita in 2020 as current achievement only 11 per capita. Paradigm shift also need in climate change management like solid waste classification and green technology industry like Kalundborg Symbiosis Approach in Denmark. Hence campaign and communication plan must be strategies by the respective agencies to disseminate the plan.

\section{Ageing Nation by 2020}

Based on World Assembly on Aging in Vienna (1982), elderly group is defined for those who above 60 years. A country is considered an ageing nation when $10 \%$ of its population is more than 60 years old. For Malaysia, 9.9\% population will be reach 60 years in 2020 and 15\% in 2030 . Arokiasamy, J.T. (1999) mentions that the increasing number of elderly means there will be an increase in the need for public facilities such as recreation facilities, transportation, appropriate toilets, housing and the availability of elevators and ramps, especially in public places. With this situation, government has to focus on installing specialized medical devices and ages care institution. Labour workforce and productivity will also affected, and possibly high taxes will be imposed on the current working population to balance the impact.

\section{Global economic downturn}

Based on planning stage, 11MP was prepared with currency rate RM3.60/per USD. Hence, target for mean USD15, 000 per capita incomes will be more difficult to achieve and many economic projections also should to be reviewed. With currency exchange rate continue week, it will also be resulting costlier import of raw and finished product. This will impact our business community as local manufacturing cost will hike up and impact the price in the market.

\section{Discussion AND CONCLUSION}

Based on the study, proven that GDP growth will lead to well-being and in Malaysia perspective, 11MP's 6 Strategic Thrusts were outlined to improve Malaysian wealth and increase MWI as well. However, actions should be taken aggressively through effective implementations and consistently improve on productivities. However, on the MWI, we would suggest some indicators to be included on the components and sub-components in order to improve index credibility. By reviewing to few international indexes, it shows that none of the organizations emphasize on spiritual and religious aspects, which are most important in our daily life. Summary of the indexes components are as per Table 2 below.

\begin{tabular}{|c|c|c|}
\hline Indices & Agencies & Factors \\
\hline \multirow{3}{*}{$\begin{array}{c}\text { Human } \\
\text { Development } \\
\text { Index }\end{array}$} & \multirow{3}{*}{$\begin{array}{l}\text { United Nation for } \\
\text { Development } \\
\text { Programmes } \\
\text { (UNDP) -2012 }\end{array}$} & Long and Healthy Life \\
\hline & & Access to Knowledge \\
\hline & & Standard of Living \\
\hline \multirow{9}{*}{$\begin{array}{l}\text { Quality of } \\
\text { Life Index }\end{array}$} & \multirow{9}{*}{$\begin{array}{c}\text { Economist } \\
\text { Intelligence Unit } \\
\text { (EIU)-2005 }\end{array}$} & Material Well-Being \\
\hline & & Health \\
\hline & & $\begin{array}{l}\text { Political Stability and } \\
\text { Security }\end{array}$ \\
\hline & & Family Life \\
\hline & & Community Life \\
\hline & & $\begin{array}{l}\text { Climate and } \\
\text { Geography }\end{array}$ \\
\hline & & Job Security \\
\hline & & Political Freedom \\
\hline & & Gender Equality \\
\hline \multirow{9}{*}{$\begin{array}{c}\text { Gross } \\
\text { National } \\
\text { Happiness } \\
\text { Index of } \\
\text { Bhutan }\end{array}$} & \multirow{9}{*}{$\begin{array}{c}\text { Royal } \\
\text { Government of } \\
\text { Bhutan-2010 }\end{array}$} & $\begin{array}{l}\text { Psychological Well- } \\
\text { Being }\end{array}$ \\
\hline & & Time Use \\
\hline & & Community Vitality \\
\hline & & Culture \\
\hline & & Health \\
\hline & & Education \\
\hline & & $\begin{array}{l}\text { Environmental } \\
\text { Diversity }\end{array}$ \\
\hline & & Living Standard \\
\hline & & Governance \\
\hline \multirow{11}{*}{$\begin{array}{l}\text { Better Life } \\
\text { Index }\end{array}$} & \multirow{11}{*}{$\begin{array}{l}\text { Organization for } \\
\text { Co-operation and } \\
\text { Development } \\
\text { (OECD)-2015 }\end{array}$} & Housing \\
\hline & & Income \\
\hline & & Job \\
\hline & & Community \\
\hline & & Education \\
\hline & & Environment \\
\hline & & Civic Engagement \\
\hline & & Health \\
\hline & & Life Satisfaction \\
\hline & & Safety \\
\hline & & Work Life Balance \\
\hline
\end{tabular}

Table 2: Examples of Few International Well-being Index Components

Based on the components above, there is no components that has been used by the indices to gauge the religious impact to the well-being, including the MWI. Religion has 
a strong impact to the well-being. Practice of religion will help society to gain many advantages including happiness and health. There were several finding of study show that the religiously committed have greater happiness and lower psychological stress compared to uncommitted. Study conducted by the University of California at Berkeley in 1971, Rodney Stark of the University of Washington in 1970 and David Williams of the University of Michigan had confirmed the finding. The seminal work of Ellison (1991, p. 80), in his review of the pre-1990s' literature on religion and wellbeing, found that religion may affect wellbeing in four ways; 1) through social integration and support; 2) through the establishment of personal relationships with a divine other; 3) through the provision of systems of meaning and existential coherence; and 4) through the promotion of more specific patterns of religious organization and personal lifestyle.

In Malaysia, religion is the main pillar in establishing harmonious and cohesive society. The first principle in National Philosophy of 'Belief in God' indicate that religion is important in people's lives in Malaysia, regardless of their religious background. Article 3 of Subsection (1) in Federal Constitution states that Islam as a religion of the Federation but other religions may be practiced in peace and harmony. The Malaysian Family Well-being Index Study 2011, published by National Population and Family Development Board, agency of Ministry of Women, Family and Community Development (KPWKM) had confirmed the importance of religion to the Malaysian. The index measured seven domains, and domain for family and religion/spirituality recorded the highest domain scores. This show that religion/spirituality has become essential aspects in Malaysian lives. In order to ensure the Malaysian Wellbeing Index is a holistic measurement to gauge well-being in Malaysia, it is proposed that the spiritual/religious aspects need to be part of the index. Domain Family and Religion/ Spirituality in the Family Well-being Index can be leveraged and enhanced to include in next Malaysian Well-being Index. Hence, further study can be carried out to conduct survey on the possibility of the inclusion of both aspects as the component in MWI in the future.

\section{REFERENCES}

Abu Bakar. A, et al, (2014), Modelling Economic Well-being and Social Well-being for Sustainability: A Theoretical Concept, The $5^{\text {th }}$ Sustainable Future For Human Security (Sustain 2014), www.sciencedirect.com, 2014.

Ahmad, N.F, et.al, (2012), Income Poverty Status and Well-being of the Vulnerable Households in Malaysia: A Comparative Study, University Putra Malaysia, 2012.

Ali. A, (2015), Rancangan Malaysia Kesebelas:, Merancang Untuk Gagal, Majlis Tindakan Ekonomi Melaka, 2015.

Arokiasamy, J.T. (1999). Malaysia's Ageing Population: Challenges in The New Millenium. Med J Malaysia Vol 54 No 4 Dec. 1999.
BCG, (2012). From Wealth to Well-being Introducing the BCG Sustainable Economic Development Assessment. Retrieved, May 2016 from: http://www.bcgtelaviv.com/documents/file122227.pdf

BCG, (2015). Why Well-being Should Drive Growth Strategies: The 2015 Sustainable Economic Development Assessment, BCG, 2015.

EPU, (2010), 10 $0^{\text {th }}$ Malaysia Plan, www.epu.gov.my, 2010.

EPU, (2012), Malaysia Well-being Report 2013, www.epu.gov.my, 2013.

EPU, (2015), 11 ${ }^{\text {th }}$ Malaysia Plan, www.epu.gov.my, 2015.

Fagan, P.F, (1996), Why Religion Matters: The Impact of Religious Practice on Social Stability, The Heritage Foundation, 1996.

Hoverd, W.J., \& Sibley, C.G. (2013) Religion, deprivation and subjective wellbeing: Testing a religious buffering hypothesis, International Journal of Wellbeing, 3(2), www.internationaljournalofwellbeing.org, 2013.

International Business Review, (2015), International Business Review of National Leaders, Business \& Innovations Volume 109, AMG Media Sdn. Bhd., 2015.

KPWKM, (2011), Family Well-being Index Study 2011, www.kpwkm.gov.my, 2011.

Laily, P. (1995). A Consumption Model for Measuring Poverty: An Exploratory Exercise. Social Indicators Research, 35(2), 129-153. http:/ / dx.doi.org/10.1007/BF01079024

Stiglitz, Joseph (2012). The Price of Inequality. London: Penguin Books.

UNDP, (2014), Human Development Report 2014, UNDP, 2014.

WeD, Wellbeing in Developing Countries (2007). Wellbeing and International Development. Retrieved, May 2016 from: http://www.welldev.org.uk/research/aims.htm

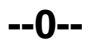

